\title{
A PROOF OF THE THREE GEOMETRIC INEQUALITIES CONJECTURED BY YU-DONG WU AND H. M. SRIVASTAVA
}

\section{Aníbal COROnel And Fernando HuAnCAS}

Abstract. In this short note the authors give answers to the three open problems formulated by Wu and Srivastava [Appl. Math. Lett. 25 (2012), 1347-1353]. We disprove the Problem 1, by showing that there exists a triangle which does not satisfies the proposed inequality. We prove the inequalities conjectured in Problems 2 and 3. Furthermore, we introduce an optimal refinement of the inequality conjectured on Problem 3.

Mathematics subject classification (2010): 26D07, 51M16.

Keywords and phrases: Geometric inequalities, power mean inequality, geometric inequality conjecture.

\section{REFERENCES}

[1] M. J. Cloud And B. C. Drachman, Inequalities: With Applications to Engineering, Springer, New York, 1998.

[2] Z. Cvetrovski, Inequalities: Theorems, Techniques and Selected Problems, (SpringerLink: Bücher), Springer, Berlin-Heidelberg, 2012.

[3] E. H. Lieb, M. Loss, ANd B. RusKaI, Inequalities: Selecta of Elliott H. Lieb, Physics and astronomy online library. U.S. Government Printing Office, 2002.

[4] D. S. Mitrinović, J. E. PeČArić, And V. Volenec, Recent Advances in Geometric Inequalities, (volume 28 of Mathematics and its Applications, East European Series), Kluwer Academic Publishers Group, Dordrecht, 1989.

[5] J. PeČArić And S. VARošAnec, A new proof of the arithmetic-the geometric mean inequality, Journal of Mathematical Analysis and Applications, 215, 2 (1997), 577-578.

[6] T. M. Rassias And H. M. SRIVAstava, (Eds), Analytic and Geometric Inequalities and Applications, (volume 478 of Mathematics and its Applications), Kluwer Academic Publishers, Dordrecht, 1999.

[7] R. A. Satnoianu, A general method for establishing geometric inequalities in a triangle, The American Mathematical Monthly, 108, 4 (2001), 360-364.

[8] S.-C. SHI AND Y.-D. WU, An artificial proof of a geometric inequality in a triangle, Journal of Inequalities and Applications, 2013 (1): 329, 2013.

[9] H. M. SRIVASTAVA, V. LOKESHA, AND Y.-D. WU, A new refinement of the janous-gmeiner inequality for a triangle, Computers \& Mathematics with Applications, 62, 5 (2011), 2349-2353.

[10] L. YANG, Recent advances in automated theorem proving on inequalities, Journal of Computer Science and Technology, 14, 5 (1999), 434-446.

[11] J. Ye, Tutorial to Mathematical Olympiad, Hunan Normal University Press, Changsha, 2003.

[12] S.-H. WU, Sharpening on a geometric inequality again, Fujian Middle School Math, (in Chinese), 10, 2001, 9-10.

[13] Y.-D. WU, V. LOKESHA, AND H. M. SRIVASTAVA, Another refinement of the pólya-szegö inequality, Computers \& Mathematics with Applications, 60, 3 (2010), 761-770.

[14] Y.-D. WU AND H. M. SRIVASTAVA, An analytical proof of a certain geometric inequality conjecture of Shan-He Wu, Appl. Math. Lett., 25, 10 (2012), 1347-1353.

[15] F.-L. ZHOU, The artful proofs of several inequalities, Fujian Middle School Math, (in Chinese), 10, 1996, 44-55. 